\title{
원조효과에 관한 파리선언 후속조치
}

원조효과에 관한 파리선언(2005년 3월 채택) 후속

\section{II. 세부내용}

조치의 일환으로 개발원조위원회 원조효과작업반은 7월 7일 8일간 파리선언 이행 점검을 위한 12 개 지 표에 대하여 검토한 바, 주요 결과는 아래와 같음.

\section{I . 핵심내용}

ㅁ 12 개 지표에 대한 기준선(Baselines) 및 목표 (Targets)에 대하여 대체로 합의에 도달(일부 지표 에 대하여 미국은 유보적 입장 표명)한 바, 우리나 라도 향후 $\mathrm{DAC}$ 가입 준비차원에서 파리선언의 내 용을 세부적으로 검토하여 이행계획을 수립해야 할 것으로 판단됨.

2008년 개도국에서 개최키로 되어 있는 원조효과 에 관한 고위급포럼을 아프리카 가나에서 개최키 로 합의함.

\section{12 개 지표에 대한 검토}

미표1(개도국의 실행가능한 개발전략 수립)과 관 련, 최소한 $75 \%$ 의 개도국이 실행가능한 개발전략 을 수립한다는 목표에 합의함.

미표2(개도국의 조달체제 및 공공재정관리체제 수 립)를 공공재정관리체제와 조달체제로 구분하여

- 공공재정관리체제에 대해서는 $50 \%$ 의 개도국이 $\mathrm{CPIA}$ (세계은행이 개도국의 예산 및 재정관리체 제를 분석 - 평가하는 등급)상 최소 1 등급(0.5점) 을 개선키로 합의하고

- 조달체제에 대해서는 $33 \%$ 의 개도국이 최소 1 등 급(총 4개 등급 중)을 개선키로 합의함.

- 지표2(개도국의 조달체제 및 공공재정관리체제 수립)와 지표5(공여국이 개도국의 조달체제 및 공공재정관리체제를 이용)가 상호 밀접한 관계가 있어 2 개 지표를 연계하여 검토한 바, 기준선 및 
구체적인 목표에 관하여 국가별로 입장 차이가 커서 논란이 많았음.

미표표(개도국의 예산에 잡히는 원조흐름)과 관련, 개도국의 정부예산에 기록되는 정부부문에 대한 원조흐름(분자)이 회계연도에 예정된 정부부문에 대한 원조흐름(분모)의 $98 \%$ 이상이 되도록 한다는 데 합의함(지표7과 밀접한 관련이 있으므로 지표7 과 연계하여 검토한 바, 분자 및 분모의 정의, 포함 범위에 대하여 논란이 많았음).

미표4(개도국의 개발전략과 일치된 조정프로그램 을 통해 개도국의 능력배양 지원)와 관련, 조정프로 그램을 통한 기술협력의 규모(분자)가 총 기술협력 규모의 $64 \%$ 이상이 되도록 한다는데 합의함(미국 은 기술협력을 개도국의 능력배양의 대용물로 간 주하는데 이의를 제기함).

미표5(공여국이 개도국의 조달체제 및 공공재정관 리체제 이용)와 관련

- CPIA상 5점 이상인(즉, 공공재정관리체제가 양 호한) 개도국에 대해서는 개도국의 공공재정관리 체제를 통하지 않는 공공부문에 대한 원조흐름을 3 분의 2 감축하고 $100 \%$ 의 공여국이 개도국 체제 를 이용한다는 목표에 합의함.

- CPIA상 3.5 내지 4.5인(공공재정관리체제가 보 통수준인) 국가에 대해서는 개도국의 공공재정관 리체제를 통하지 않는 공공부문에 대한 원조흐름 을 3 분의 1 감축하고 $90 \%$ 의 공여국이 개도국의 체제를 이용키로 합의함(이에 대하여 미국은 유 보적 입장 표명).

미표6(프로젝트관리사무소(PIU) 병행 설치를 피함
으로써 개도국의 능력배양 지원)과 관련, Parallel $\mathrm{PIU}$ 의 정의를 기존 부처/기관의 프로젝트 이행조 직과 별도로 설립되는 또는 기존 부처의 기능과 중 복되는 조직으로서 직원들의 보수를 외부로부터 지급받거나 또는 외부의 재정지원기관에 보고하게 되어 있거나 또는 외부기관이 정한 절차를 따르는 조직으로 합의한 후에 이러한 조직을 3 분의 2 감축 키로 하였음.

미표7(예측가능한 원조 제공)과 관련, 예측가능성 의 정의를 회계연도에 지출(예정된 지출)되는 원조 흐름을 분자로 하고, 공여국이 회계연도에 지원을 약속한 원조흐름을 분모로 하여 예측가능성의 목 표를 $90 \%$ 이상으로 하기로 합의함.

미표표(Untied aid)은 당초부터 양자간 원조의 불구 속성(Untied) 확대를 위해 계속 노력한다는 목표에 합의한 사항으로서 별다른 논의가 없었음.

미표(Programme-based approaches에 따른 원 조 제공) 관련, 전체 원조흐름 중에서 Programmebased approach에 따라 제공되는 원조규모가 3 분 의 2 이상이 되도록 한다는데 합의함.

미표표 10 (공여국의 공통 사절단 파견 및 국가분석작 업의 공통실시) 관련, 원조현장에 파견되는 공여국 공통사절단이 전체 사절단의 $40 \%$ 가 되도록 한다는 데 합의하고 공여국이 공통으로 실시하는 국가분 석작업은 전체 국가분석작업의 3 분의 2 가 넘도록 하기로 합의함.

미표11(원조성과 평가시스템) 관련, 투명하고 심사 가능한 성과평가시스템이 없는 공여국 비율을 절 반 이하로 줄이는데 합의함. 
ㅁ 지표12(상호 책임) 관련, 원조효과에 관하여 공여국 과 개도국이 합의한 사항의 이행여부를 공통으로 평가하기로 한 바, 이러한 평가에 모든 개도국이 참 가하기로 합의함.

\section{2. 향후 계획}

말ㄹ선언문은 지난 3 월 채택 당시, 12 개 지표별 목 표에 대해서는 구체적 합의를 보지 못하여 $\mathrm{DAC}$ 의 원조효과작업반으로 하여금 2005년 9월 이전에 합의하도록 위임함에 따라 지난 5 월 30 일 31 일간 1 차 검토를 하였고 이번에 2 차 검토를 통해 대체적 합의를 보았음.
미난번 1차 검토 및 금번 2 차 검토에는 $\mathrm{OECD}$ 회 원국 외에도 12 개 개도국 및 $\mathrm{WB}, \mathrm{IMF}, \mathrm{UNDP}$, 지 역개발은행 등 국제기구 대표들이 동등한 자격으 로 참석한 바, 금번 합의사항을 파리선언문에 참가 한 여타 국가들에게 통보하여 의견을 문의하기로 하였음.

ㅁㄸㄸ한 파리선언문 이행사항을 점검하기 위한 2008 년도 고위급포럼을 아프리카 가나에서 개최키로 하였음.

[자료:주오이시디 대표부] 